\title{
DIE HEILIGE NAGMAAL EN KERKLIKE TUG
}

\author{
A. le R. du Plnny \\ Departement Kerkreg \\ Potchefstroomse Universiteit vir Christelike Hoër Onderwys \\ POTCHEFSTROOM \\ 2520 \\ Abetract \\ HOLY COMMUNION AND ECCLESLASTICAL DISCIPLINE
}

This article intends to give an account of the Reformed Confession conceming aspects of the Lord's Supper and Church Discipline.

Attention is given to relevant articles of faith in the Confession, the form for the sacrament of the Lord's Supper and cerain articles of the Church Order of the Gereformeerde Kerke in Suid-Afrika.

These documents, originating from the Reformation of the Ith and 17th century, are still upheld by many Reformed Churches. In contrast to this, since the period of the so-called Nadere Reformasie" until recent times, the Confersion of the Reformed Churches, in casu the Heidelberg Catechism as well as particular articles of the Chunch Order, has been strongly criticised or neglected.

A shon neview is given of the historical background to the establishment of the Reformed beliefs concerning the Lord's Supper and Church Discipline ngarding this sacmament

In conclusion nelevant parts of Scripture, for mample 1 Corinthians 11 , are dealt with in onder 10 determine whether the Confession confarms ea Scripture and ta emphasize the correspondence between the particular anticles of faith and the Wond of God

\section{INLEIDING}

In ons reformatoriese belydenis, in die klassieke Nagmaalsformulier en in die kerkorde wat sy oorsprong in die Reformasie het, word op 'n prominente wyse uitdrukking gegee aan die leer van die kerk met betrekking tot die onderwerp Nagmaal en kerklike tug.

Aangesien die belydenis oor hierdie aspekte van die leer van die Gereformeerde Kerke sedertdien bevraagteken, onderbeklemtoon, misverstaan en selfs ernstig bestry word, is dit van aktuele belang dat opnuut daaroor besin sal word.

Die bedoeling in hierdie artikel is om rekenskap te gee van ons belydenis oor hierdie aangeleentheid, en daarom word agtereenvolgens op die volgende aspekte gelet: 
- 'n weergawe van wat daaroor in die konfessie, die Nagmaalsformulier en kerkorde geleer en gereël word;

- strominge en tendense sedert die Reformasie tot vandag om die aktualiteit van die onderwerp te illustreer;

- die prominente plek wat die Nagmaal as sakrament en die kerklike tug as een van die sleutels van die koninkryk van die hemele in die reformatoriese teologie inneem;

- die reformatoriese ontwikkelingsgang wat tot konfessionele formuleringe aanleiding gegee het, en daaraan ten grondslag lê;

- die toets van die Skrif oor hierdie aspek van ons belydenis asook oor die reëlings daaroor in die formulier en kerkorde.

\section{DIE DRIE FORMULIERE VAN EENHEID, DIE KLASSIEKE NAGMAALSFORMULIER EN DIE DORDTSE KERKORDE}

Dit is opvallend hoe die Drie Formuliere van Eenheid (in besonder die Heidelbergse Kategismus), die klassieke Nagmaalsformulier en die Dordtse Kerkorde die heiligheid van die Nagmaal bely en beskerm.

In hierdie geskrifte word naas die klem op die suiwere bediening van die Woord, besondere aksent op die suiwere bediening van die sakramente en die kerklike tug, as die merktekens van die ware kerk geplaas (Nederlandse Geloofsbelydenis, artikel 29). Dit is die konstitutiewe faktore by die ontstaan en voortbestaan van die kerk. Die verkondiging van die evangelie en die Christelike tug is die sleutels van die koninkryk van die hemele waardeur die koninkryk vir die gelowiges oopgesluit en vir die ongelowiges toegesluit word (Heidelbergse Kategismus, Sondag 31).

Volgens die gereformeerde konfessie (veral Sondag 30 van die Heidelbergse Kategismus) staan die Nagmaal oop vir diegene wat hulle self deeglik beproef het, en deur hulle belydenis en lewe getuienis bied van 'n opregte geloof. Die Nagmaalstafel is egter geslote vir diegene wat onchristelik lewe: vraag 82 van die Heidelbergse Kategismus lui s6: "Moet die mense ook aan die Nagmaal toegelaat word wat met hulle belydenis en lewe wys dat hulle ongelowig en goddeloos is?". Die antwoord lui: "Nee, want so word die verbond van God ontheilig en sy toorn oor die hele gemeente opgewek. Daarom is die Christelike kerk volgens die bevel van Christus en sy apostels verplig om sulke mense met die sleutels van die koninkryk van die hemel uit te sluit totdat hulle verbetering van hulle lewe bewys." Die Nederlandse Geloofsbelydenis (artikel 35) beklemtoon dit dat die ongelowige die sakrament tot sy verdoemenis ontvang; hoewel die ongelowige die sakrament sou kon ontvang, ontvang hy nie daarmee vir Christus nie, want Hy word slegs aan gelowiges, aan weergeborenes, gegee: "Daarom behoort 
niemand daarheen te gaan as hy homself nie eers deeglik ondersoek het nie, sodat hy nie tot sy eie oordeel eet en drink as hy van hierdie brood eet en uit hierdie beker drink nie" (1 Kor 11:29).

Die klassieke Nagmaalsformulier stem met die belydenis ooreen, en in die gedeelte wat oor die selfondersoek handel, blyk dit duidelik dat verharde en volhardende sondaars, veragters van God en sy Woord en die sakramente, nie tot die Nagmaal toegelaat is nie, en ook geen deel aan die ryk van Christus het nie!

In die lig hiervan het die kerke gedurende die Reformasie dit ordelik in die kerkordes gereël

- dat die ouderlinge met huisbesoek toesig hou oor die leer en lewe van die gemeente (vgl. Dordtse Kerkorde, artikel 23);

* dat "tot die heilige Nagmaal word alleen diegene toegelaat wat volgens gebruik van die plaaslike kerk belydenis van die Gereformeerde godsdiens gedoen het en 'n goeie getuienis van 'n vrome wandel besit" (Kerkorde, GKSA, artikel 61);

* dat "diegene wat hardnekkig die vermaning van die kerkraad verwerp en ook dié wat 'n openbare of ander growwe sonde gedoen het, moet van die sakramente van die Here afgehou word." (Kerkorde, GKSA, artikel 76).

Die Reformasie van die sestiende en vroeg sewentiende eeu het dic kerklike tug en die heilige Nagmaal baie nou met mekaar in verband gebring. Teen 1563 was die orde reeds duidelik: konfessioneel, liturgies en kerkordelik was dit prinsipieel en prakties vasgestel en gereël dat daar besondere toesig en dissipline oor die Nagmaal moes wees. Die reformatoriese visie op die Nagmaalstug was teen 1563 in beginsel geformuleer in die kerkorde van die Palts. Dit het 'n afsluiting gevorm van wat ongeveer 35 jaar vroeër in Basel begin het (Van 't Spijker, 1980:367). Die ontwikkeling na 1563 tot met die sinode van Dordrecht in 1618 /19 was alleenlik 'n verfyning en voltooiing van reeds geformuleerde beginsels.

\section{STROMINGE EN TENDENSE VANAF DIE REFORMASIE VAN DIE 16e EEU TOT DIE 20e EEU}

Dit is opmerklik hoe die aksente oor Nagmaalsviering en Nagmaalstug vanaf die 17e eeu tot die $20 \mathrm{e}$ eeu verlê is.

Die Nagmaal kan altyd min of mcer beskou word as 'n barometer waarmee die geestelike klimaat en teologiese stand van sake in die kerklike lewe gemeet word (Graafland, 1980:249). 
Na die Reformasie breek die tyd van die sogenaamde Nadere Reformasie aan. In die tydperk van die Nadere Reformasie (17e en 18e eeu) het die aksent meer op die mens as op God geval: in die Reformasie het God se genade alleen (sola gratia) voorop gestaan. Die Nagmaal is 'n bewys van God se genade: Christus het die Nagmaal vir die gelowige kinders van God ingestel sodat hulle Christus wat daardeur voorgestel word, kan ontvang (Nederlandse Geloofsbelydenis, artikel 35). Die Nadere Reformasie plaas die mens op die voorgrond: sy staat en sy waardigheid of onwaardigheid om aan die Nagmaalstafel aan te sit, beheers die denke oor die Nagmaal. Die labadisme dra ook daartoe by dat die tydperk gekenmerk is deur 'n gees van piëtisme en bevindelikheid. Aan die ander kant het die rasionalisme ook 'n groot invloed op die Nagmaal en Nagmaalsviering gehad. Die gevolg was dat die aksent rondom die Nagmaalsviering verskuif het van Christus en sy heil tot die Christen en sy staat. Die aandag is al hoe meer toegespits op die mens en sy onwaardigheid om Nagmaal te vier. Die invloed van die labadisme waarvolgens iemand feitlik in 'n sondelose staat moet wees voordat hy Nagmaal mag gebruik, het daartoe gelei dat al minder mense Nagmaal gebruik het (vgl. Graafland, 1980:248-279; Lekkerkerker, 1961:116 e.v.).

Die rasionalisme en die gepaardgaande geestelike vervlakking ten opsigte van die Nagmaalsviering het tot gevolg gehad dat onkundiges en onverskilliges op oppervlakkige wyse tot die Nagmaal toegetree het. Dit het weer daartoe gelei dat piëtistiesbeskroomde lidmate al meer beweeg het tot die myding van die Nagmaal (Graafland, 1980:323).

Hierdie twyfel en onsekerheid oor die Nagmaalsviering het in die $19 \mathrm{e}$ eeu voortgeduur. Dit was die eeu waarin die verligting en modernisme in skerp reaksie teen sowel die regsinnigheid van die Dordtse sinode as die piëtisme was (Lekkerkerker, 1961:131; Graafland, 1980:323 e.v.). Die gevolg was dat die Nagmaal gedevalueer was en al minder belangstelling gaande gemaak het.

In die algemeen kan die $19 \mathrm{e}$ eeu beskou word as 'n tydperk van groot verwarring oor die Nagmaal en veral oor die vraag wie toegelaat mag word. Diepgaande besinning oor hierdie aspekte het slegs in geringe mate voorgekom (vgl. Graafland, 1980:330).

Nuwe belangstelling in die Nagmaal en Nagmaalsviering begin veral in die 20e eeu (vgl. Graafland, 1980:331 e.v.). Vrae wat besonderlik aan die orde gestel en bespreek was, handel oor konkrete sake soos onder andere wie tot die Nagmaal toegelaat mag word, oor selfbeproewing, oor kommunikante in die algemeen en oor die ouderdom van kinders wat aan die Nagmaalstafel mag aansit. In menige opsig vind ons in gereformeerde kringe 'n reaksie teen piëtistiese en rasionalistiese opvattings oor die Nagmaal waar die klem te veel op die mens en sy hoedanighede geplaas is (Bavinck, 1930:560-563; Bouwman, 1934:386 e.v.). In die tweede helfte van die 20e eeu ontstaan daar 
besondere belangstelling oor sake soos interkommunie, kinderkommunie, kerkeenheid en Nagmaal en ekumenisiteit in die Nagmaalsviering (vgl. Aalbers, 1971; Hartveld, s.j.: 88 e.v.).

Die algemene opvatting was dat die Nagmaalsviering die sentrum en hoogtepunt van die Christelike samekoms is (Graafland, 1980:348; Boelens, 1979:7). Onder leiding van die Wêreldraad van Kerke en vanuit eie inisiatief het die Nederlandse Hervormde Kerk, die Gereformeerde Kerken in Nederland en die Rooms Katolieke Kerk ernstig gestreef na groter toenadering en na interkommunie. Hulle het hulle beywer vir'n ruimer beleid (sic!) ter wille van oop Nagmaalsvieringe, en in die proses het die gereformeerde belydenis sterk in gedrang gekom. Daar is geredeneer dat soos wat die doop alle Christene met mekaar verbind, so behoort die eenheid ook konkreet in die Nagmaal belewe te word (Boelens, 1979:20 e.v.).

Selfs kinders (dooplidmate) behoort to die Nagmaal toegelaat te word (al is dit onder sekere voorwaardes), want - so word geredeneer - "wie voor de kinderdoop kiest zal dit doen op gronden, die ook het recht op kinderkommunie funderen" (Boelens, 1979:83; vgl. ook Aalbers(1971) en Hartveld (s.j.:88 e.v.)).

Ernstige kritiek word teen reformatoriese standpunte gelewer aangesien die Reformasie te veel klem op 1 Korintiërs 11:29 sou plaas, en te sterk aksent sou lê op die verstandelike begrip en kennis van geloofswaarhede by die kommunikant. Die kritiek behels verder dat die Drie Formuliere van Eenheid te min aandag gee aan die subjektiewe verwerking van die kennis. Die saak van toelating tot die Nagmaal word beklemtoon ten koste van die daad van die individuele belewing van die geloof in die Nagmaal. Dit word ook vergeet dat groot en klein gelykwaardig moet meedoen aan die viering van die Nagmaal (Boelens, 1979:83-93; Graafland, 1980:333 e.v.).

Graafland (1980:358-360) se konklusie aan die einde van sy oorsig oor "de stormachtige ontwikkeling in die avondmaalspraktijk" (gedurende die 19e en 20e eeu), is dat die heilige karakter van die Nagmaal vervang is deur 'n opvatting waarvolgens die Nagmaal slegs 'n ekumeniese maaltydskarakter verkry het. Verder stel hy dat selfs binne reformatoriese kerke die skriftuurlike verkondiging oor die Nagmaal deur skrifkritiese benaderinge vervlak is en deur laasgenoemde oorheers word. So het die reformatoriese visie op die Nagmaal en veral op die Nagmaalsviering totaal in die slag gebly.

Dit kom voor asof die strewe na die eenheid van die kerk en die belangstelling wat ekumenisiteit in ons tyd ook in die geledere van reformatoriese kerke in Suid-Afrika geniet, tot gevolg het dat die frekwensie van oop Nagmaalsvierings toeneem, en dat interkommunie tussen kerke met ' $n$ reformeerde belydenis en anglikaanse kerke 'n werklikheid begin word. 
Die oproep van Graafland (1980:360) is terdeë ter sake. Hy bepleit naamlik 'n hernude besinning oor die Nagmaal, oor Nagmaalsviering en die toesig daaroor volgens die Skrifgetuienis en die reformatoriese belydenis.

Kerke met 'n gereformeerde belydenis (waarin onder meer die gesag van die Skrif, asook die heiligheid van die Nagmaal en die noodsaak van die kerklike tug erken en bely word), en kerke wat gevolglik die klassieke gereformeerde liturgiese formuliere en 'n gereformeerde kerkregering wil handhaaf, is feitlik in 'n situasie gedwing waarin hulle hulle opnuut moet rekenskap gee van sake soos die heilige Nagmaal en die kerklike tug en oor sogenaamde oop of geslote Nagmaalstafels. Wat is die agtergrond en wortels van ons belydenis en ordereèlings oor hierdie aangeleenthede? Wat is reg met betrekking tot toesig oor en toelating tot die Nagmaal? Vir wie is die Nagmaal ingestel en wie het in die oë van God die reg en roeping om daaraan deel te hê?

\section{SAKRAMENT VAN DIE NAGMAAL EN DIE KERKLIKE TUG}

In die reformatoriese teologie en belydenis neem die sakramente 'n besondere plek in, veral in reaksie teen die sakramentsleer van die Rooms Katolieke Kerk. Die aandag aan die sakramente was grotendeels ook die oorsaak daarvan dat die kerklike tug groot prominensie geniet het.

Dit is opmerklik dat Calvyn byvoorbeeld die vervalsing van die sakramente in die Roomse Kerk aan die ontbreking van kerklike tug by Rome toeskryf (Dankbaar, 1941:8). Kerkverval, sakramentsverval en tugverval loop vir Calvyn hand aan hand, want die suiwere bediening van die Woord en sakramente is vir hom juis die konstitutiewe faktore van die kerk (Institusie, IV, 1, 10). Sonder Woord en sakramente is die ware kerk nie moontlik nie (Dankbaar,1941:4).

Calvyn het ernstig gewaak oor die heiligheid van die kerk. Hy het geoordeel dat indien die kerk waarlik die moeder van die gelowiges wil wees, die kerk self uit pastorale bewoëndheid die taak het om oor die leer en lewe van die kerk te waak. So kry die kerklike orde, in besonder die tug en die amp vir hom aktuele betekenis (Dankbaar,1941:6). Die bediening van die tug onder leiding van die ampte dien juis daartoe om oor die heiligheid van die sakramente te waak (Institusie, IV, 12, 5).

Hieruit blyk reeds dat Calvyn 'n besondere relasie tussen kerk, amp, sakramente en tug wil handhaaf.

Die sakramente is vir die gelowiges, die kerk, ingestel. Die doop teken die geestelike daad waardeur God die kerk in aansyn roep; die doop beseël die wedergeboorte waar- 
deur die kerk geestelik ontstaan; dit begrens die kerk as die nuwe wêreld in die ou wêreld, en omvat alle gelowiges, selfs in hulle geslagte. Deur die Nagmaal wil God die kerk as sodanig bewaar en versterk; die Nagmaal bou en versterk die kerk in sy ware geestelike eenheid met God en met mekaar. Daarom is dit bedoel vir diegene wat reeds wedergebore is, en die beseëling daarvan in die doop ontvang het (Snyman, 1977:32). Deur die bediening van die tug word toesig gehou oor die heiligheid van die sakramente. Waar die doop meer met die kerk as universele gemeenskap van gelowiges in verband gebring kan word, daar is die Nagmaal as sakrament wat volg op die doop, 'n aangeleentheid vir die lokale kerk, waar toesig oor gelowiges gehou kan word.

Dit is noodsaaklik dat daar toesig en tug oor die sakramente sal wees, want in die Nagmaalsviering is die kerk met sy diepste kerkwees besig, in sy totale uniekheid en heiligheid en afgesonderdheid. Daar vind ons die koninkryk van God wat in gehoorsaamheid en afhanklikheid van Christus feestelik maaltyd hou. Nagmaalsviering is 'n koninkryksgebeure! Die Koning voed ons deur die werking van die Heilige Gees met Christus self (vgl. Van 't Spijker, 1980:369).

By die behandeling van 'n onderwerp wat onder meer oor kerklike tug handel, is dit noodsaaklik dat ons ons verantwoord oor die betekenis van die woord tug.

Die uitdrukking kerklike tug kom as sodanig nie in die Bybel voor nie, hoewel die gedagte en begrip duidelik daarin figureer (Visser, 1982:1 e.v.). Die duidelikste term

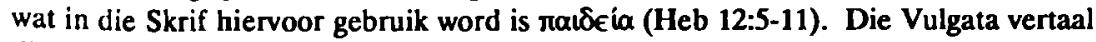
dit met disciplina. Volgens Heystek (1987: 13-17) het die begrip tug veral twee basiese elemente, naamlik 'n opvoedende, sondevoorkomende bediening aan die gehoorsame kinders van God, en tweedens, 'n bestraffende, teregwysende bediening aan sondaars.

Plomp (1969:62 e.v.) het aangetoon dat Calvyn die woord disciplina in verskillende betekenisse gebruik het:

* vir 'n goed georganiseerde Christelike lewe;

- as aanduiding van die kerklike orde ter wille van die ordelike verloop van sake in die kerk, soos geformuleer in geldende voorskrifte vir die kerk;

- vir die vermanende en bestraffende optrede teenoor sondaars.

Calvyn noem dit die morum disciplina (tug oor lewenswandel) en ook disciplina excommunicationis (tug wat bestaan in of uitloop op ekskommunikasie). Hy beskou dit as die mag wat die kerk het om reg te spreek vanweë die regsbevoegdheid van die kerk (potestas in iurisdictione; Institusie IV, 11, 1). 
Ons gebruik die woord tug in laasgenoemde betekenis en in die tweede betekenis wat Heystek daaraan heg, naamlik tug wat as bediening van die sleutels van die koninkryk van die hemele beskou moet word (Matt 16 en Heidelbergse Kategismus, Sondag 31), dit wil sê in die betekenis waarvolgens die kerk deur die tug die suiwerheid van die kerk moet bewaar en beskerm. In sy Ordonnances Ecclesiastiques van 1537 (wat feitlik as sy Nagmaalsorde beskou kan word) laat Calvyn die bespreking van die tug onmiddellik by die Nagmaalsviering aansluit (Dankbaar, 1941:199).

Aangesien die kerklike tug in die gereformeerde konfessie so prominent voorkom en besondeslik aan die Nagmaal en Nagmaalsviering gekoppel is, is dit nodig dat ons ons vergewis van die historiese agtergrond, die ontwikkelingsgang en die motivering daarvoor.

\section{REFORMATORIESE ONTWIKKELINGSGANG}

Die persoon wat met sy standpunte sekerlik die grootste invloed op die 16e eeuse reformatoriese visie oor die Nagmaal en kerklike tug uitgeoefen het, was Calvyn. Balke (1980:179) meen dat Calvyn se Nagmaalsleer geheel en al oorspronklik was. Tog is dit duidelik dat hy ten opsigte van die Nagmaalsgebruik en die noodsaak van die tug nie net leraar was nie, maar ook leerling van ander hervormers, byvoorbeeld Luther en Bucer, en ook andere.

Ons wil aantoon - slegs kortliks en kursories - dat daar ten opsigte van hierdie sake 'n ontwikkeling was wat by Calvyn 'n bepaalde diepte bereik het, en daarna in konfessionele, liturgiese formuliere en kerkordes finale gestalte verkry het. Hierin wil ons veral op die prominensie van die Nagmaalstug konsentreer.

\subsection{Luther}

Selfs vanuit Luther se Nagmaalsbeskouing (bekend as die konsubstansiasie-leer) waarvolgens Christus self reëel in die Nagmaal aanwesig is, mag iemand wat onwaardig is juis om daardie rede nie toegelaat word om Christus te ontvang nie (Plomp, 1969:26). Onverskilliges en verharde sondaars moet gebied word om van die Nagmaal weg te bly (Exalto, 1980:140). Op grond van tekste soos Matteus 18:15 e.v., 1 Korintiërs 5:1 e.v., 2 Tessalonisense 3:14 en Esegiël 3:17 e.v. behoort sulke mense uiteindelik ook deur die ekskommunikasie van die Nagmaal uitgesluit te word (Plomp, 1969:16-17). Wie Christus op onwaardige wyse ontvang, ontvang Hom tot hul eie oordeel en skade (Exalto, 1980:137-138). 
Luther was egter aarselend oor die praktiese toepassing van die tug omdat hy van oortuiging was dat die gemeente en selfs die predikante nog te onryp was om dit te hanteer, en omdat hy gevrees het vir 'n herlewing van pouslike tirannie. Daarby het hy, volgens sy twee-ryke leer, hierdie verantwoordelikheid as die owerheid se taak beskou (Plomp, 1969:18-19).

\subsection{Zwingli, Bullinger en Oecolampadius}

Calvyn het baie waardering vir Luther se werk gehad (vgl. Van 't Spijker, 1985). Omdat hy by Luther gelees het dat Oecolampiadius en Zwingli die Nagmaal totaal uitgehol het sodat daar slegs leë en ydele figure oorgebly het, het hy van hulle geskrifte vervreem geraak (a.w.:8).

Zwingli en Bullinger het ten opsigte van die Nagmaalstug feitlik presies die teenoorgestelde standpunt as Calvyn gehuldig. Hulle het gemeen dat verharde sondaars juis na die Nagmaal moes kom, en indien hulle sou weier, moes hulle uit die land verban word. Uitsluiting van die Nagmaal was vir Zwingli en Bullinger 'n onaanvaarbare tugmiddel, want die Nagmaal sou dan juis God se genadige handeling met die sondaar wees waarvan niemand hom mag onttrek of afskei nie. Bullinger meen dat die bewys daarvoor lê in die feit dat die Here vir Judas Iskariot tot die Nagmaal toegelaat het (Plomp, 1969:26-30).

Oecolampadius het 'n belangrike bydrae ten opsigte van die noodsaaklikheid van die Nagmaalstug gelewer. In sy rede oor die kerklike tug wat hy op versoek aan die raad van Basel voorgelè het, pleit hy in $\mathbf{1 5 3 0}$ dat tug as 'n kerklike saak beskou moet word, dat oor die suiwerheid van die Nagmaal gewaak moet word, en dat daar vir hierdie doel 'n raad van ouderlinge soos in die tyd van die apostels ingestel moet word - veral met die oog op die Nagmaalstug. Hoewel die raad nie al sy voorstelle aanvaar het nie, het hy tog hiermee 'n bydrae gelewer wat groot invloed uitgeoefen het op Bucer (Van 't Spijker, 1970:205 e.v.; 1980:367-368; Plomp, 1969:31-35).

\subsection{Bucer}

Oecolampadius se gedagtes het spoedig in Straatsburg, waar Bucer werksaam was, bekend geword. Dit het Bucer beïnvloed en geïnspireer, en toe die doperse mense ook nog in groot getalle na Straatsburg gestroom het, en hulle die kerk juis verwyt het dat daar geen tug was nie, het Bucer duideliker as ooit die noodsaak van kerklike tug besef (Van 't Spijker, 1970:205-210). Bucer was van mening dat die tug deur die ouderlinge bedien moet word, en dat dit veral daarop gerig moet wees om die sogenaamde ver- 
wonde en gebroke skape weer terug te bring. Hy bepleit ook 'n vorm van boete of bekering, want daarsonder kan niemand tot die Nagmaal toegelaat word nie. Verharde sondaars moet as valse bokke beskou word wat deur die tug uit die gemeente uitgesluit moet word (Plomp, 1969:36-39). As noodsaaklike toegangsvereiste tot Nagmaalsgebruik het Bucer die belydenis van geloof (ook konfirmasie genoem) ingevoer (Van't Spijker, 1980:368).

Hoewel Bucer nie sy gedagtes in Straatsburg kon realiseer nie, het hy wel daarin geslaag om dit in Hessen te doen. Verder het sy menings in die Franssprekende vlugtelinggemeente in Straatsburg, waar Calvyn van 1538-1541 gearbei het, tereggekom (Plomp, 1969:41; Van 't Spijker, 1980:368).

\subsection{Calvyn}

In Straatsburg het Calvyn op hierdie wyse erfgenaam geword van grondliggende werk wat reeds gedoen is deur Bucer en andere. Hy het dit verder sodanig uitgebou en ontwikkel dat invloed op die hele gereformeerde wêreld uitgeoefen is (Van 't Spijker, 1980:368)

Hy het beklemtoon dat die tug aan die gemeente toevertrou is, en dat die ouderlinge in besonder geroep is om dit te bedien (Institusie, IV, 11, 1; IV, 12, 7).

Reeds in 1537, in Genève, het Calvyn en ander predikante 'n aantal tugartikels vir die raad opgestel waarin 'n reeling gevra word om te voorkom dat die Nagmaal besoedel word. Persone wat Jesus nie as hulle Here bely nie, kan tog nie Nagmaal gebruik nie; slegs beproefde lede van Christus (approuvez membres de lesuchrist) mag aansit (Plomp, 1969:146).

Calvyn het dit duidelik gestel dat belydenis van geloof en rekenskap van geloof aan die tug vooraf gaan. Wie tot die Nagmaal wil toetree, moet eers deur geloof en doop lidmaat wees, en wie belydende lidmaat is, moet tot die Nagmaal toetree (Wielenga, 1913:42; Plomp, 1969:147).

Kategetiese onderrig aan gedoopte kinders, en aan volwassenes wat nog nie gedoop is nie, asook toesig oor die leer en lewe van belydende lidmate was vir Calvyn belangrike voorwaardes vir Nagmaalsgebruik (Balke, 1980:223; Plomp, 1969:194 e.v.; Pont, 1981:32 e.v.). Nuwe lidmate was ook aan ondersoek onderwerp oor die hoofinhoud van die leer. Lidmate is persoonlik ondervra oor die stand van sake by hulle huise, of alles ordelik en vreedsaam verloop, en of hulle sedelik reg lewe en die eredienste gereeld bywoon (Balke, 1980:223). 
Behalwe die selfondersoek waartoe elke Nagmaalsganger kragtens 1 Korintiërs 11:28 opgeroep word, het Calvyn daarop gestaan dat die kerk ook amptelik ondersoek moet doen oor die leer en lewe van die kommunikante (Dankbaar, 1941:200).

Kinders wat ondersoek is, en blyke daarvan kon gee dat hulle die hoofinhoud van die leer begryp, is reeds op 10-jarige leeftyd tot die Nagmaal toegelaat (Dankbaar, 1941:201). Dit het nie beteken dat hulle onderrig daar opgehou het nie, want voortaan moes hulle by die predikant aanmeld om nader onderrig te word tot ongeveer op 15 jarige leeftyd (Plomp, 1969:69).

Bouwman (1912:81) toon aan hoe Calvyn en Farel juis op grond van hulle eis tot deeglike toesig oor die Nagmaal in 1538 probleme met die raad van Genève gekry het. Calvyn en Farel het geweier om tydens 'n erediens die Nagmaal te bedien omdat niemand daar waardig was om die Nagmaal te ontvang nie. Die gevolg was dat die twee uit die stad verban is. Toe het Calvyn op versoek van Bucer na Straatsburg vertrek.

In Straatsburg het Calvyn op 'n meer pastorale wyse met die lidmate omgegaan, omdat die owerheid nie ingemeng het nie. Die gebruik was dat elkeen hom persoonlik by die predikant aanmeld met die oog op ondersoek. Na gelang van omstandighede is sommiges onderrig, andere vermaan of bemoedig - juis uit eerbied vir die sakramente (Dankbaar, 1941:200). Hoewel hy streng was, het hy anders as die anabaptiste gewaarsku teen 'n te streng opvatting en eiewillige afhouding van die Nagmaal (a.w.:202). Sy standpunt was dat duidelik onderskei moet word tussen die aanbied en die ontvang van die sakrament: dit word aan alle gelowiges aangebied, maar nie almal ontvang dit nie, omdat daar ook hipokriete is. Vir diegene wat dit onwaardiglik ontvang, is (let wel: nie word nie) dit soos gif; hulle stel hulle daarmee bloot aan die straf van God (Institusie IV, 17,34). Onder waardigheid vir die Nagmaal verstaan hy dat iemand met berou, liefde en geloof die Nagmaal moet gebruik. Dit is 'n waardigheid wat nie uit onsself is nie, maar iets wat ons op grond van God se barmhartigheid ontvang (Institusie IV, 17,42).

In Genève het 'n uitgebreide reêling oor die Nagmaalsgebruik, toesig oor en vereistes tot deelname daaraan, gegeld (vgl. Pont, 1981:41 e.v.; bepalinge 141-166 van die kerkorde). Baie lidmate is daar ook van die Nagmaal afgehou (vgl. Plomp, 1969:218-219 wat al die gevalle bespreek). Enkele redes vir die afhouding van die Nagmaal is die volgende: terugval in Roomse katolisisme, godslasterlike en ketterse opvattinge, gebrekkige geloofskennis, ongereelde bywoning van Woord- en sakramentsbediening. belediging van Calvyn en ander predikante, belediging van Franse immigrante, onsedelikhede, dans en onbetaamlike liedere, dobbel, druk van bedenklike geskrifte, ensovoorts (Plomp, 1969:222-223). In Genève is die gemeente (stad) vir die eerste keer in wyke ingedeel, en dan het die predikant en die ouderling die lidmate tuis besoek. 
Iemand is spesiaal aangewys om te sorg dat niemand oorgeslaan word nie. Hierdie reeling het die Roomse biegstelsel vervang (Plomp, 1969:353).

Dit is opvallend dat Calvyn in sy Nagmaalsliturgie ook 'n geleentheid ingeruim het waartydens daar op 'n skerp en persoonlike manier gesê word: "... in die naam en op gesag van ons Here Jesus Christus sluit ek uit alle afgodsdienaars, lasteraars, ..." (Dankbaar, 1941:209). Maarten Micron het in London hierby aangesluit, maar verder gegaan: hy het volgens sy Nagmaalsliturgie, na die preek die name laat afkondig van die wat nie toegelaat was nie (Vinke, 1835:29; Dankbaar, 1956:15).

\subsection{Calvyn, die klassieke Nagmaalsformulier en kerkordelike bepalinge}

Die opvattings van Calvyn tesame met die invloed van verskillende reformatore op die reformatoriese kerke wat oraloor in Engeland en Europese lande ontstaan het, het daartoe gelei dat die tyd ryp geword het vir die ordelike formulering van geskrifte soos die Nederlandse Geloofsbelydenis, die Heidelbergse Kategismus, kerkordes en ook die bekende klassieke Nagmaalsformulier.

Die klassieke Nagmaalsformulier is van Olevianus afkomstig, en is oorspronklik in die Paltse kerkorde van 1563 opgeneem. Hierdie formulier is in opdrag van Frederik III opgestel, en Datheen het dit uit Duits in Nederlands vertaal. Die kerkvergaderings van die 16e en 17e eeu het dit telkens vir gebruik in die kerke voorgeskryf: Wesel 1568, hoofstuk VI, artikel 13; 's Gravenhage 1586, artikel 55; Dordt 1618/19, artikel 62 (vgl. Wielenga, 1913:15-22).

Die belangrikste bron waarvan Olevianus gebruik gemaak het, was weer eens Calvyn se Nagmaalsliturgie en -formuliere wat hy reeds in Straatsburg en in Geneve opgestel het (Dankbaar, 1941:207 e.v.). Calvyn het in Straatsburg wat hierdie saak betref,aangesluit by gebruike wat reeds daar in swang was. Die Straatsburgse Nagmaalsliturgie en -formuliere het die aspek van Nagmaalstug reeds verwoord, en was ook ' $n$ liturgie wat veral in die Franse gemeentes, asook in Londen nagevolg is (a.w.:208). In Genève het Calvyn op sy Straatsburgse liturgie voortgebou en ook by Farel aangesluit. Dit is veelseggend dat hy in Genève daarop aangedring het dat die volkstaal gebruik moet word sodat mense 'n goeie begrip van die sakrament moet hê (a.w.:209). Uit die gegewens wat Calvyn in Straatsburg en Genève tot sy beskikking gehad het, het die aksent telkens op die noodsaak van Nagmaalstug en sake soos ekskommunikasie geval. Dit was algemeen dat onwaardiges nie tot die Nagmaal toegelaat kon word nie. Daar was algemene eenstemmigheid (in Straatsburg, Genève, London - waar a'Lasco en Micron hule eie formulier gehad het - en ook in Frankryk) dat katkisasie, belydenis en Nagmaal 'n onafskeidbare trio gevorm het (Wielenga, 1913:42). 
Olevianus het vir sy formulier van die formuliere van Micron en Wurttemberg en veral van die Geneefse formulier van Calvyn gebruik gemaak (Dankbaar, 1941:211-212; 1956:1-30; Van 't Spijker, 1980:375).

Dit is moontlik minder bekend dat die Nagmaalsformuliere van die 16e eeu vocrafgegaan is deur 'n sogenaamde ondersoeking van die geloof, 'n gedeelte waarin vrae geformuleer is wat vooraf aan die gemeente gevra is voordat hulle gaan om Nagmaal te gebruik. Dit moes hoofsaaklik dien as 'n hernude bevestiging en belydenis van hulle geloof, en dat hulle hulle onderwerp aan die kerklike tug (Vinke, 1835:1-14; Wielenga, 1913:40). In die klassieke Nagmaalsformulier is dit egter weggelaat omdat hierdie saak van ondersoek met huisbesoek en tugoefening deur die kerkrade hanteer is. Toe reeds is kerkordelike bepalinge hieroor geformuleer.

Teen 1563 was die kwessie oor toelating tot die Nagmaal asook reëlings oor die toesig en tug in beginsel besleg. Die Paltse formulier van 1563 asook die Heidelbergse Kategismus wat in 1563 opgestel was, stem met mekaar oor hierdie aangeleenthede ooreen.

In 1568 het die konvent van Wesel die resultaat van hierdie ontwikkelingsgang soos volg verwoord: "Men zal niemand tot des Heeren heilig avondmaal toelaten, dan die vooraf belijdenis des geloofs gedaan heeft en zich aan de kerkelijke tucht onderwerpt" (artikel 87; Pont, 1981:86). Vanaf 1571 tot $1618 / 19$ is soortgelyke formuleringe met dieselfde strekking in al die kerkordelike bepalinge oor die Nagmaal behou (vgl. Pont, 1981; Bouwman, 1912:225).

Hiermee word alleen uitdrukking gegee aan die feit dat die Nagmaal geen oop maaltyd is nie, maar wel geslote. Beter gestel: die Nagmaal is in 'n bepaalde sin wel oop, vir diegene wat hulle onderwerp aan die verkondiging van die evangelie as die bediening van die sleutelmag; vir hulle word die koninkryk en daarmee ook die Nagmaalstafel oopgesluit (Nagmaalsviering is immers 'n koninkryksgebeure). Vir diegene wat hulle nie onderwerp aan die Woord van God nie, en hulle nie bekeer nie, vir hulle moet verkondig word dat hulle van deelname aan die Nagmaalstafel uitgesluit is; maar ook van die gemeente en van die koninkryk indien hulle in sonde volhard. So funksioneer die sleutel van die Christelike tug (Heidelbergse Kategismus, Sondag 31), en staan oop en geslote tafels in die nouste verband met die bediening van die sleutelmag! (vgl. Kuyper, s.j. :238). Wie pleit vir oop Nagmaalsvierings, waar geen bepaalde toesig en ondersoek vooraf gaan nie, verwerp die leer oor die sleutels van die koninkryk van die hemele.

In artikel 61 van die Dordtse Kerkorde - waar oor die toelating tot die Nagmaal gehandel word - word hierdie beginsel prakties gereël. Hiervolgens is getuienis van die gereformeerde godsdiens, asook van 'n vrome lewenswandel noodsaaklik. Dit geld 
sowel belydende lidmate van die bepaalde gemeente as lidmate van ander kerke in kerkverband. Daarom staan artikel 82, waar oor attestate gehandel word, in direkte verband met artikel 62 .

Ongelukkig het die sinode van 1964 van die Gereformeerde Kerke in Suid-Afrika die artikel probeer verduidelik deur agter die uitdrukking "ander kerken in hakies by te voeg "van dieselfde kerkverband". Dit bots met die oorspronklike bedoeling van die artikel. Die eintlike bedoeling van die artikel is om te stel dat niemand, waarvandaan hy ook al afkomstig is, sonder goeie getuienis van sy leer en lewe toegelaat kan word nie. Daarom reêl die artikel ook dat diegene wat uit ander kerke (in kerkverband) of uit ander kerkgemeenskappe afkomstig is, eers volgens attestaat of na 'n ondersoek deur die kerkraad bewys moet gee van goeie getuienis voordat hulle lidmate kan word en dan as sodanig tot die Nagmaal toegelaat kan word. Die artikel het nie bedoel om oor gaste te handel nie.

By die beantwoording van die vraag of gelowiges as gaste uit ander kerkgemeenskappe tot die Nagmaalsviering toegelaat kan word, sal wel dieselfde beginsels moet geld wat die belydenis stel en wat in artikel 61 van die kerkorde gerëel is. Die sinodes van die Gereformeerde Kerke van Suid-Afrika van 1961 (acta:119) en 1967 (acta:589) het besluit dat dit 'n saak is vir die plaaslike kerk. Dit is bekend dat Calvyn nie beswaar gehad het teen die toelating van Lutherane by die Nagmaal nie, of dat gereformeerdes by ' $n$ Lutherse Nagmaal mag aansit nie. Die kerkraad behoort in sodanige situasie vas te stel of die persoon lidmaat is van 'n kerk wat in belydenis genoegsaam met die leer van die kerk ooreenstem, of die persoon in sy kerk toegelaat sou word en of die persoon se persoonlike leer en lewe met die ware leer van die kerk ooreenkom (vgl. Bouwman, 1934:391; Rutgers, 1922:156-166; Kuyper, s.j.:239).

\section{GETOETS AAN DIE SKRIF}

\subsection{Alleen vir gelowiges}

Die konfessie, formulier en kerkorde is duidelik daaroor dat die Nagmaal alleen vir wedergebore gelowiges ingestel is. Aktuele vrae in hierdie verband is byvoorbeeld die volgende: waarom verwys die Nederlandse Geloofsbelydenis in artikel 35 na goddelose mense wat ook die sakrament kan ontvang, en word daar spesiaal van Judas Iskariot en Simon die towenaar melding gemaak wat albei die sakrament ontvang het? Verder: indien gelowiges beide sakramente naamlik die doop en die Nagmaal ontvang, waarom mag gedoopte kinders wat nog nie belydenis van geloof afgelé het nie, nie Nagmaal gebruik nie? 
In hierdie verband wil ons die lig van die Woord van God hierop laat val. Uiteraard beperk ons ons tot enkele gegewens. In sy kommentaar op Handelinge 2:42 wys Haenchen (1971:191) daarop dat die gelowiges in Jerusalem hulle inderdaad as 'n afgesonderde groep onderskei het, en dat hulle dit juis in die Nagmaal as gemeenskaplike maaltyd toon dat hulle van nie-Christene onderskei moet word. Ook in Handelinge 20:7 en 11 blyk dit duidelik dat die Nagmaal 'n maaltyd van gelowiges is (vgl. Bruce, 1977:408).

Nêrens in die Skrif lees ons dat ongelowiges die Nagmaal gevier het nie. Die feit dat artikel 35 van die belydenis na Judas Iskariot en Simon die towenaar verwys, word deur Van Bruggen (1971:183) as ongelukkige voorbeelde beskou. Ons lees inderdaad nêrens in die Skrif dat Simon die towenaar aan die Nagmaal deelgeneem het nie. Uit die berigte volgens die evangelies van Markus, Matteus, Lukas en Johannes is dit ook nie duidelik of Judas werklik aan die eintlike Nagmaal deelgeneem het nie. Calvyn (1846:198) sê in sy kommentaar op Lukas 22:21 dat ons nie presies duidelikheid daaroor het nie, maar erken dat dit moontlik kon wees. Lukas is die enigste een wat so 'n moontlikheid laat ontstaan. Bavinck (1930:568) meen dat die verwysing na Judas weinig dogmatiese betekenis het, want hy was teenwoordig as dissipel van die Here, en so het hy hom ook voorgedoen. Heystek (1987:130-148) gaan weliswaar nie in sy bespreking van Judas op hierdie probleem in nie, maar bewys dat hy ten spyte van sondevoorkomende waarskuwings en tug van Jesus persoonlik in sy sonde volhard het. $\mathrm{Hy}$ het derhalwe nie waarlik vir Christus deur die Nagmaal ontvang nie, soos die belydenis dit stel.

Ten opsigte van die vraag of die doop reeds toelating tot die Nagmaal bied, antwoord die voorstaanders daarvan gewoonlik dat wie die betekenende saak, naamlik Christus besit, ook reg op die tekens self het (Bavinck, 1930:560; ook punt 3 hierbo). Uit die standpunte van Calvyn, soos ons dit reeds aangetoon het, is dit duidelik dat hy in elk geval die kinders op 'n baie vroeër stadium of jonger ouderdom, naamlik 10 jaar, tot die Nagmaal toegelaat het, maar dan nadat hulle blyke moes gee dat hulle die hoofinhoud van die leer ken, en amptelik ondersoek is. Bavinck (1930:560 e.v.) voer heelwat gronde aan waarom die doop alleen nie genoegsaam is tot toelating van die Nagmaal nie. Die belangrikste hiervan is sy verwysing na 1 Korintiërs 11:26-30. Kinders wat nog nie genoeg kennis het nie, en onryp is, is nie in staat tot die eis van selfondersoek nie. Die doop kan aan passiewe kinders bedien word, maar die Nagmaal vereis aktiewe selfondersoek, selftug en kennis van ellende, verlossing en dankbaarheid, asook bewuste geloofsbelydenis (vgl. formulier; Jansen, 1952:268). 


\subsection{Korintiërs 11}

Uit die voorafgaande bespreking van ons reformatoriese erfenis het dit in al die geskrifte (konfessie, formulier en kerkorde) duidelik geblyk dat ten opsigte van Nagmaal en kerklike tug 1 Korintiërs 11:27-32 besonder sentraal staan. Die vraag is of dit reg is wanneer ons daaruit aflei dat daar iets soos selftug en kerklike tug is, en dat wanneer ' $n$ goddelose of verharde sondaar toegelaat is, God se toorn oor die ganse gemeente opgewek word.

In 1 Korintiërs 11:20-21 onderskei Paulus duidelik tussen die gewone (hoof)maaltyd van die Grieke bekend as $\delta \epsilon$ เाvov (Grosheide, 1957:305), en die Nagmaalsmaaltyd,

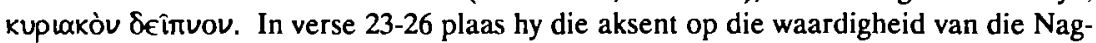
maal van die Here waar brood en beker hul waardigheid het (a.w.:312). In vers 27 trek hy die gevolgtrekking ( $\ddot{\omega} \sigma \tau)$ ) dat die Nagmaal dus nie onwaardig gebruik mag word nie; God gee dit in die waardigheid van die Here self, en daarom moet dit as sodanig ontvang word. Wie dit onwaardig ontvang, verbreek nie die waardigheid van die Nagmaal nie, maar bly voor God daarvoor verantwoordelik (Calvyn,1960:251). Uit Hebreërs 6:6 en 10:29 blyk dit dat wie Christus se kruis verag, sy kruisiging vir sy rekening neem! Die Nagmaalsganger moet dus bewustelik en in volle verantwoordelikheid voor God die Nagmaal gebruik.

In vers 28 verklaar Paulus hoe die Nagmaal wel gebruik moet word: "Maar die mens moet homself beproef en so van die brood eet en uit die beker drink".

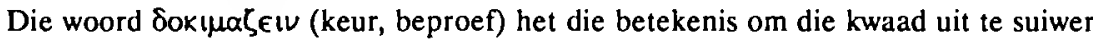

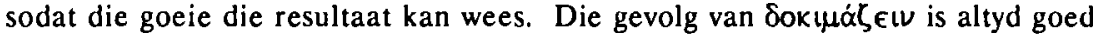
(Grundmann, 1968:260). Hierdie opdrag word spesiaal aan gelowiges gegee, want die bedoeling van so 'n selfondersoek of selfbeproewing kan nooit beteken dat jy moet besluit of jy Nagmaal mag gebruik nie, maar hoe jy dit gaan doen (Delleman, s.j.:141; Grosheide,1957:313).

Dit is 'n opdrag tot selftug sodat jy in die gestalte van verootmoediging, gelouter en geheilig deur die Woord en Gees sal gaan om juis in die geloof versterk te word (Fil 1:10; Ef 5:10). So moet hulle Nagmaal gebruik (kal oütws - 1 Kor 11:28).

Hierdie opdrag om die Here in 'n beproefde toestand te ontmoet, is in ooreenstemming met die hele Skrif:

* As Jakob na Betel vertrek om vir die Here 'n altaar op te rig, dan moet al die vreemde gode uit sy huis verwyder wees en moet hulle hulle reinig en ander klere aantrek (Gen 35:1-4); 
* As Israel Pasga wil vier, moet hulle al die suurdeeg uit hulle huise verwyder, en sewe dae lank moet hulle ongesuurde brode eet. Uit 1 Korintiërs 5:7-8 blyk dit dat die verwydering van die suurdeeg simbolies was van die verwydering van die suurdeeg van die sonde (vgl. Delleman, s.j.: 142-143; Grosheide, 1957:145).

In 1 Korintiërs 11:29 ("want hy wat eet en drink sonder om te besef dat dit die liggaam van die Here is, bring daardeur 'n oordeel oor homself") gee Paulus die rede waarom selfondersoek voor Nagmaal so belangrik is: hy stel hom voor die oordeel van God!

In verse 30-32 blyk dit dat omdat die gemeente reeds verkeerd Nagmaal gebruik het, die oordeel van God in hulle midde werksaam is. Daar is naamlik swakkes en sieklikes en afgestorwenes onder hulle. God het hulle nog nie veroordeel nie, maar Hy tugtig hiermee die gemeente sodat hulle nog gered kan word (vgl. Grosheide, 1957:314 e.v.).

Dit is opvallend dat Paulus van die enkelvoud in vers 29 na die meervoud (julle) in vers 30 oorgaan. So is dit duidelik dat die individu nie losstaan van die gemeente nie, en dat die gemeente ook 'n verantwoordelikheid ten opsigte van elke individu het (vergelyk Pop, 1965:261).

Deur selftug en kerklike tug voorkom ons die veroordeling van God soos wat dit die ongelowige wêreld sal tref. Wie hom onderwerp aan die tug van die Here se Woord, sal vrymoediglik deur die sakrament van die Nagmaal die liggaam en bloed van Christus ontvang sodat hy uiteindelik ook in die oordeel van God by die voleinding bewaar kan word (vgl. 1 Korintiërs 11:32; Pop, 1965:262).

\section{SLOT}

Waar die kerk met die gebruik van die sakrament van die Nagmaal in sy diepste kerkwees besig is, moet die kerk as draer van die sleutels van die koninkryk van die hemele waak oor hierdie heilige handeling. In God se groot genade het $\mathrm{Hy}$ aan sy kinders ook hierdie genademiddel gegee waardeur Christus self aan ons aangebied word. Hy eis van ons dat ons dit met ' $n$ ware geloof en in ' $n$ beproefde staat en gesindheid sal ontvang. Alles wat Hy in sy Woord aan ons oor die Nagmaal en die kerklike tug geopenbaar het, het die kerk onder leiding van die Heilige Gees, deur gebed en stryd heen eindelik konfessioneel vasgestel en op grond daarvan ordelik gereël in 'n formulier en kerklike ordereëlings. Aangesien dit die toets van die Skrif kan deurstaan, moet ons hierdie reformatoriese erfenis soos kosbare goud bewaar - tot eer van God en tot opbou van sy kerk. 


\section{BIBL JOGRAFIE}

(Alleen aangehaalde bronne word vermeld)

AALBERS, BJ. 1971. Kinderen aan hel avondmaal? Kampen : Kok.

BALKE, W. 1980. Het avondmaal by Calvyn. (In Van 'i Spijker, W., Exalto, K. en Van Driel, L. ned. By brood en beker. Goudriaan : De Groot. p. 178-225)

BAVINCK, H. 1930. Gereformeerde dogmatiek. Vierde deel. Kampen : Kok.

BOELENS, S J.WIM 1979. Tafel en gastheer. Toenadering by interkommunie en ambt. Baarn : Ten Have bu.

BOUWMAN, H. 1912. De kerkelijke tuch1 naar het Gereformeerde kerkrecht. Tweede deel. Kampen : Kok.

BOIJWMAN, H. 1934. Geteformeerd kerkiecht. Tweede deel. Kampen : Kok.

BRUCE, F.F. 1977. Commentary on the Book of Acts. London : Marshall, Morgan \& Scott.

CALVYN, J. s.j. Institutie of de onderwijzing in de Christelike religie. Amsterdam : Bottenburg.

CALVYN, J. 1846. Commentary on a harmony of the evangelists, Matthew, Mark, and Luke. (Translator Pringle, W.). Edinhurgh: The Calvin Iranslation sociely.

CALVYN, J. 1960. The firsl episile of Paul the aposile to the Corinthians. (Translator Torrance, J.W.) Edinburgh : Oliver and Boyd

DANKBAAR, W.F. 1941. De sacramenisleer van Calvyn. Amslerdam : H.. Paris.

DANKBAAR, W.F. 1956. Marlen Micron. De Christelicke ordinancicn der Nederlantscher ghemeinten te London (1554). 's Gravenhage : Martinus Nijhoff.

DELlemaN, TH. s.j. Het heilige avondmaal. Amsierdam : De Pauw.

EXALTO, K 1980. Het avondmaal by Luther. (In Van 'I Spijker, W., Balke,W., Exalto, K. en van Driel, L., reds. Ay brood en beker. Goudriaan : De Groot. p. 106-148)

FEENSTRA, J.G. 1966 . Onze Geloofsbelijdenis. Kampen : Kok.

GEREFORMEERDE KERKE IN SUID-AFRIKA. 1961. Handelinge van die vier-en-dertigste sinodale vergadering.

GEREFORMEER DE KER KE IN SUID-AFRIKA. 1967. Handelinge van die ses-en-dertigste sinodale vergadering

GRAAFLAND, C. 1980. Nadere Reformatie. G.Voetius/A.Arakel/J.Verschuir. (In Van 't Spijker e.a reds. By brood en beker. Goudriaan: De Grool. p. 248-281).

GRAAFL.AND, C. 1980. Het avondmaal in de 19e en 20e ceuw. (In Van 't Spijker, W. e.a. red. By brood en beker. Goudriaan : Dc Groot. p. 323 - 362).

GROSHEIDE, F.W. 1957. De eerste brief aan de kerk le Korinthe (In Commentaar op het Nieuwe Testament). Kampen : Kok

GRUNDMANN, W. 1968. dokimatsoo (In Kittcl, G. red. Theological dictionary of the New Testament II:255-260. Grand Rapids, Michigan : Eerdmans).

HAENCHEN, E. 1971. The Acts of the aposiles A commentary. Oxford : Blackwell.

HARTVELD, G.P. s.j. Tasibaar evangelie. (In Nieuwe commentaar Heidelbergse catechismus, deel 1II.). Aalien : De Graafschap.

HEYSTEK, N.P. 1987. Die plek van die lugbediening in die pasıoraal. Potchefstroom. 445p. (Proefskrif (Th. D.) - PU vir CHO)

JANSEN, JOH. 1952. Korte verklaring van de kerkorde der Gereformecrde kerken. Kampen : Kok.

KUYPER, A. s.j. E voto dordraceno. Toelichting op den Heidelbergschen catechismus. Derde decl. Kampen : Kok

LEKKERKER KER, A.F.N. 1961. De lafel des heren. Baarn : Bosch \& Keuning N.V.

PLOMP, J. 1969. De kerkelijke iucht by Calvyn. Kampen : Kok.

PONT, A.D. 1981. Die historiese aglergronde van ons kerklike reg. Pretoria/Kaapslad : HAUM.

POP, F.J. 1965. De eerste brief van Paulus aan de Corinthiërs. (In De prediking van het Nieuwc Testament). Nijkerk : Callenbach N.V. 
RUTGERS, F.L. 1922. Kerkelijke adviezen. Tweede deel. Kampen : Kok

SNYMAN, WJ. 1977. Nuwe en ou dinge "Uit die skat van die koninkryk". (In Snyman, P.C. red.) Potchefsiroom : Pro Rege.

VAN BRUGGEN, J. 1971. Hel amen der kerk. De Nederlandse geloofsbelijdenis toegelicht. Goes : Oosterbaan \& I $e$ Cointre N.V.

VAN T SPIJKER, W. 1970. De amblen bij Mariin Bucer. Kampen : Kok.

VAN 'T SPIJKER, W. 1980. Het klassieke avondmaalsformulier. (In Van 't Spijker, W. e.a.reds. Bij brood en beker. Goudriaan : De Groot. p. 369-422)

VAN 'T SPIJKER, W. 1985. Luther en Calvyn. De invloed van Luther op Calvyn blijkens de Institutie. Kampen : Kok.

VINKE, H.E. 183.5 Over den oorsprong van het voorhouden van eenige vragen aan de Gemeente bij de voorbereiding tot het Heilige Avondmaal. (In Kist, N.C. en Royards, HJ. reds. Archief voor kerkelijke geschiedenis, inzonderheid van Nederland. Leiden : J. Luchtmans. p. 1-40).

VISSER, J. 1982. Die tug oor ampsdraers. 'n Kerkregtelike en kubernetiese studie. Potchelstroom. 624 p. (Proefskrif (Th.D.) - PU vir CHO)

WIELENGA, B. 1913. Ons avondmaalsformulier. Kampen : Kok 
